\title{
Pemodelan Regresi Zero Inflated Poisson (ZIP) dan Hurdle Model Pada Kasus Penyakit Tetanus Neonatorum
}

\author{
Rina Sri Kalsum Siregar \\ Badan Pusat Statistik Kabupaten Sleman; Jl. Purbaya, Tundan, Mlati, Sleman, Yogyakarta; \\ Indonesia; rina.siregar@bps.go.id
}

\begin{abstract}
Abstrak
Peristiwa terjadinya Tetanus Neonatorum sudah menjadi peristiwa yang langka (rare cases) karena dari 38 kabupaten kota di Jawa Timur pada tahun 2014 terdapat 68 persen wilayahnya sudah tidak terjadi kasus Tetanus Neonatorum. Pada penelitian ini variabel dependen yang digunakan adalah data count, yaitu jumlah kasus penyakit Tetanus Neonatorum yang terjadi di Jawa Timur menurut kabupaten/kota, sehingga analisis yang dapat digunakan adalah pengembangan dari regresi linier yaitu regresi Poisson. Namun permasalahan lain yang dihadapi adalah proporsi nilai nol pada variabel dependen diatas 50 persen. Overdispersi pada data dapat terjadi karena proporsi nilai nol yang berlebih pada variabel dependen (excess zeros). Jika data mengalami overdispersi, maka regresi Poisson tidak baik digunakan dalam menganalisis data. Untuk mengatasi masalah tersebut model yang dapat digunakan antara lain model regresi Zero Inflated Poisson (ZIP) dan Hurdle Model. Nilai AIC dari regresi Zero-Inflated Poisson (ZIP) menunjukan nilai terkecil dibandingkan nilai AIC yang dihasilkan oleh Hurdle Model yaitu sebesar 88,248, sehingga model ZIP dipilih namun akan dilakukan kembali pengujian overdispersi, dari hasil pengujian ternyata terdapat overdispersi sehingga dilakukan pemodelan lebih lanjut menggunakan ZINB.
\end{abstract}

Kata Kunci: Hurdle, Tetanus Neonatorum, ZINB, ZIP

\begin{abstract}
The occurrence of Tetanus Neonatorum has become a rare case because of the 38 districts in East Java in 2014 that there are 68 percent of the area that has not occurred in the case of Tetanus Neonatorum. In this study the dependent variable used is the data count, which is the number of cases of Tetanus Neonatorum disease that occur in East Java according to districts / cities, so the analysis that can be used is the development of linear regression, Poisson regression. But another problem faced is the proportion of zero values in the dependent variable above 50 percent. Over dispersion in the data can occur because of the proportion of zero values that are excessive in the excess zeros. If the data is over dispersed, Poisson regression is not well used in analyzing data. To overcome this problem the models that can be used include the Zero Inflated Poisson
\end{abstract}

Euclid, p-ISSN 2355-1712, e-ISSN 2541-4453, Vol. 6, No. 2, pp. 117- 129 CLembaga Penelitian Universitas Swadaya Gunung Jati (UGJ), Cirebon. 
(ZIP) regression model and the Hurdle Model. The AIC value of the Zero-Inflated Poisson regression (ZIP) shows the smallest value compared to the AIC value generated by the Hurdle Model which is 88,248 , so the ZIP model is selected but over dispersion testing will be carried out.

Keywords: Hurdle, Tetanus Neonatorum, ZINB, ZIP

\section{Pendahuluan}

Tetanus Neonatorum adalah tetanus yang terjadi pada bayi usia hari ke 3 sampai dengan hari ke 28 setelah lahir (Simbolon, 2008; Tengah, 2012). Menurut WHO pada tahun 1988 terdapat 787.000 bayi baru lahir yang meninggal akibat Tetanus Neonatorum (Departemen Kesehatan RI, 2000). Sehingga, pada akhir tahun 1980 perkiraan angka kematian tahunan global dari Tetanus Neonatorum adalah sekitar 6,7 kematian per 1000 kelahiran hidup sehingga hal ini merupakan masalah kesehatan masyarakat yang penting (Pusat Data dan Informasi, Kementerian Kesehatan RI, 2012). Sejak tahun 1989 WHO menargetkan eliminasi Tetanus Neonatorum. Sebanyak 104 dari 161 negara berkembang telah mencapai keberhasilan tersebut. Namun masih terdapat 57 negara yang memiliki persoalan yang signifikan mengenai Tetanus Neonatorum sehingga UNICEF, WHO, dan UNFPA pada desember 1999 setuju memperpanjang masa Eliminasi Tetanus Maternal dan Neonatal (ETMN) hingga tahun 2005.

Indonesia melaksanakan ETMN sejak tahun 1979 dengan kebijakan Program Pengembangan Imunisasi (PPI) yaitu suatu program untuk mengeliminasi Tetanus Neonatorum (TN) dimulai dengan pemberian vaksin Tetanus Toxoid (TT) kepada ibu hamil dan calon pengantin dan bayi disertai pemberian vaksin dipteri, pertusis, tetanus atau DPT (Kemenkes RI, 2012; Sugiharto \& Ristrini, 2017). Angka kematian bayi (AKB) di Indonesia pada tahun 2007 sebesar 34 kematian per 1000 kelahiran hidup (Mahmudah, Cahyati, \& Wahyuningsih, 2011; Tantijati \& Bantas, 2006). Kematian tertinggi pada periode neonatal di Indonesia sebesar 19 kematian per 1000 kelahiran hidup dan penyebab tertingginya adalah penyakit Tetanus Neonatorum, sehingga pada tahun 2007 Tetanus Neonatorum masih merupakan masalah kesehatan di Indonesia.

Menurut profil data kesehatan di Jawa Timur pada tahun 2014 peristiwa terjadinya Tetanus Neonatorum sudah menjadi peristiwa yang langka (rare cases) karena dari 38 kabupaten kota di Jawa Timur terdapat 68 persen wilayahnya sudah tidak terjadi kasus Tetanus Neonatorum. Faktor-faktor yang mempengaruhi Tetanus Neonatorum menurut Departemen Kesehatan antara lain adalah cakupan imunisasi TT2+ terhadap jumlah ibu hamil, tenaga 
bidan terhadap jumlah bayi, dan cakupan kunjungan neonatus lengkap terhadap jumlah bayi.

Sejumlah peneliti telah mendokumentasikan hasil penelitian mereka terkait pemodelan kasus Tetanus Neonatorum (Lestari \& Wulandari, 2014; Rahayu, Devianto, \& Yozza, 2016; Nusantara \& Purhadi, 2015; Amaliana, Sa'adah, \& Wardhani, 2018). Lestari dan Wulandari (2014) menjelaskan model terbaik yang dihasilkan dari regresi Zero-Inflated Generalized Poisson (ZIGP) menghasilkan 2 variabel prediktor yang berpengaruh signifikan terhadap jumlah kasus Tetanus Neonatorum yaitu persentase ibu bersalin ditolong dukun dan persentase kunjungan neonatus 3 kali (KN3 atau KN Lengkap). Namun, hasil ini belum meninjau faktor-faktor lain yang diduga mempengaruhi kasus Tetanus Neonatorum lainnya, seperti ekonomi, kondisi lingkungan, dan pendidikan dalam lingkup individu sendiri di tiap kabupaten/kota. Selanjutnya, persentase ibu bersalin yang ditolong tenaga kesehatan dan persentase kemiskinan merupakan faktor-faktor yang berpengaruh signifikan terhadap jumlah kasus tetanus neonatorum di Wilayah Regional 2 Indonesia (Sumatera) tahun 2012, 2013 dan 2014 yang dihasilkan dari model regresi Poisson (Rahayu, Devianto, \& Yozza, 2016). Di sisi lain, Nusantara dan Purhadi (2015) menggunakan Geographically Weighted Zero-Inflated Poisson Regression (GWZIPR) dalam memodelkan kasus penyakit Tetanus Neonatorum di Jawa Timur yang memberikan hasil bahwa peluang tidak terjadi kasus penyakit Tetanus Neonatorum di setiap kabupaten/kota di Jawa Timur dipengaruhi oleh persentase tenaga bidan, ibu bersalin ditolong tenaga kesehatan, dan cakupan kunjungan neonatus lengkap. Terakhir, hasil pemodelan pada kasus Tetanus Neonatorum di Jawa Timur menggunakan regresi ZINB pada berbagai proporsi zero-inflation menghasilkan variabel prediktor persentase ibu bersalin yang ditolong tenaga kesehatan, persentase kunjungan $\mathrm{K} 1$ pada ibu hamil, dan persentase imunisasi TT1 pada ibu hamil berpengaruh signifikan terhadap banyaknya kasus Tetanus Neonatorum di Jawa Timur (Amaliana, Sa'adah, \& Wardhani, 2018). Oleh karena itu, model regresi dapat dijadikan alat yang dapat digunakan untuk memodelkan kasus Tetanus Neonatorum di Jawa Timur dengan berbagai kelebihan dan kekurangannya, sehingga model yang dihasilkan dapat menentukan variable-variabel yang berpengaruh terhadap kasus tersebut.

Berdasarkan hal-hal di atas, penulis tertarik untuk melihat variabel manakah yang memiliki pengaruh diantara variabel-variabel yang dimasukkan kedalam model, yaitu cakupan imunisasi TT2+ terhadap jumlah ibu hamil, tenaga bidan terhadap jumlah bayi, dan cakupan kunjungan neonatus lengkap terhadap jumlah bayi pada jumlah kasus penyakit Tetanus Neonatorum yang terjadi di Jawa Timur. Salah satu analisis yang bisa digunakan adalah analisis regresi. Analisis regresi yang sering digunakan adalah analisis regresi linier. Hanya saja analisis ini bisa digunakan saat variabel dependen berupa data kontinu. Pada penelitian ini variabel dependen yang digunakan adalah data count, yaitu 
jumlah kasus penyakit Tetanus Neonatorum yang terjadi di Jawa Timur menurut kabupaten/kota, sehingga analisis yang dapat digunakan adalah pengembangan dari regresi linier yaitu regresi Poisson. Namun permasalahan lain yang dihadapi adalah proporsi nilai nol pada variabel dependen diatas 50 persen. Overdispersi pada data dapat terjadi karena proporsi nilai nol yang berlebih pada variabel dependen (excess zeros). Jika data mengalami overdispersi, maka regresi Poisson tidak baik digunakan dalam menganalisis data. Untuk mengatasi masalah tersebut model yang dapat digunakan antara lain model regresi Zero Inflated Poisson (ZIP) dan Hurdle Model. Kemudian dipilih model terbaik menggunakan AIC. Dari model terbaik, dilakukan kembali pengujian overdisperi. Jika masih dideteksi terjadi overdispersi maka model regresi Zero Inflated Negative Binomial (ZINB) menjadi solusi.

\section{Metode Penelitian}

\subsection{Data dan Variabel Penelitian}

Data yang digunakan pada penelitian ini merupakan data sekunder yang didapatkan dari Data Profil Kesehatan Provinsi Jawa Timur Tahun 2014. Data berupa data per kabupaten di Provinsi Jawa Timur. Variabel penelitian yang digunakan adalah sebagai berikut:

$\mathrm{Y}=$ Jumlah kasus Tetanus Neonatorum

$\mathrm{X}_{1}=$ Persentase Cakupan imunisasi TT2 + terhadap jumlah ibu hamil

$\mathrm{X}_{2}=$ Persentase tenaga bidan terhadap jumlah bayi

$\mathrm{X}_{3}=$ Persentase cakupan kunjungan neonatus lengkap terhadap jumlah bayi

\subsection{Prosedur Penelitian}

Langkah-langkah yang dilakukan dalam penelitian menggunakan ZIP adalah sebagai berikut:

1. Melakukan analisis deskriptif

2. Melakukan pemeriksaan multikolinieritas antara variabel prediktor.

3. Setelah terpenuhi syarat tidak terjadi multikolinieritas dilakukan pemodelan menggunakan regresi ZIP.

4. Melakukan pemodelan menggunakan Hurdle Poisson

5. Membandingkan kebaikan model ZIP dan Hurdle dengan melihat nilai AIC terkecil

6. Melakukan pengujian overdispersi pada model terbaik

7. Apabila terjadi overdispersi, gunakan model ZINB

8. Penarikan kesimpulan

\section{Hasil dan Pembahasan}




\subsection{Analisis Deskriprif}

Variabel respon yang digunakan dalam penelitian ini adalah banyak jumlah kasus Tetanus Neonatorum (Y) di Provinsi Jawa Timur Tahun 2014. Pada tahun 2014 jumlah kasus Tetanus Neonatorum di Provinsi Jawa Timur mencapai 33 kasus, dengan kasus terbanyak berjumlah 9 kasus di Kabupaten Bangkalan dengan 4 kejadian kematian. Sementara, kedua terbanyak setelah Kabupaten Bangkalan adalah Kabupaten Sampang dengan jumlah 6 kasus dengan jumlah kematian sebanyak 5 kejadian.

Terdapat tiga variabel prediktor yang diduga berpengaruh terhadap variabel respon jumlah kasus Tetanus Neonatorum di Provinsi Jawa Timur. Keempat variabel prediktor tersebut antara lain adalah persentase cakupan imunisasi $\left(X_{1}\right)$, persentase tenaga bidan terhadap jumlah bayi $\left(X_{2}\right)$, dan persentase cakupan kunjungan neonatus lengkap terhadap jumlah bayi $\left(X_{3}\right)$. Tabel 1 menjelaskan gambaran secara deskriptif dari variabel yang digunakan dalam penelitian ini.

Tabel 1. Statistika Deskriptif Variabel

\begin{tabular}{lcccc}
\hline \multirow{2}{*}{ Keterangan } & \multicolumn{4}{c}{ Variabel } \\
\cline { 2 - 5 }$(1)$ & $\mathrm{Y}$ & $X_{1}$ & $X_{2}$ & $X_{3}$ \\
\hline Rata-rata & $(2)$ & $(3)$ & $(4)$ & $(5)$ \\
Minimum & 0,8684 & 36,92 & 0,0137 & 88,31 \\
Maksimum & 0 & 0 & 0,0002 & 62,57 \\
\hline
\end{tabular}

Berdasarkan Tabel 1, diketahui bahwa pada tahun 2014 di Provinsi Jawa Timur, variabel prediktor memiliki rata-rata yang berbeda jauh dari variabel prediktor lainnya, yaitu variabel persentase tenaga bidan terhadap jumlah bayi $\left(X_{2}\right)$. Nilai ratarata dari variabel $X_{2}$ relatif lebih kecil dibandingkan variabel prediktor lainnya yang menggambarkan masih sedikitnya jumlah tenaga bidan di Jawa Timur tahun 2014 dibandingkan dengan jumlah bayi yang ada. Sama halnya dengan variabel persentase cakupan imunisasi $\left(X_{1}\right)$ juga memiliki nilai rata-rata dibawah 50 persen, hal ini menunjukkan bahwa kesadaran dan antusiasme ibu hamil pada imunisasi masih sangat kecil oleh karena itu seharusnya dilakukan upaya agar para wanita hamil melakukan imunisasi sejak kandungan agar terhindar dari bakateri tetanus pada saat melahirkan.

Pada penelitian ini diperoleh jumlah konsumsi minuman beralkohol pada sebulan terakhir menghasilkan nilai respon nol yang sangat besar, yaitu sebesar 68 persen. Grafik variabel respon (y) disajikan pada Gambar 1. 


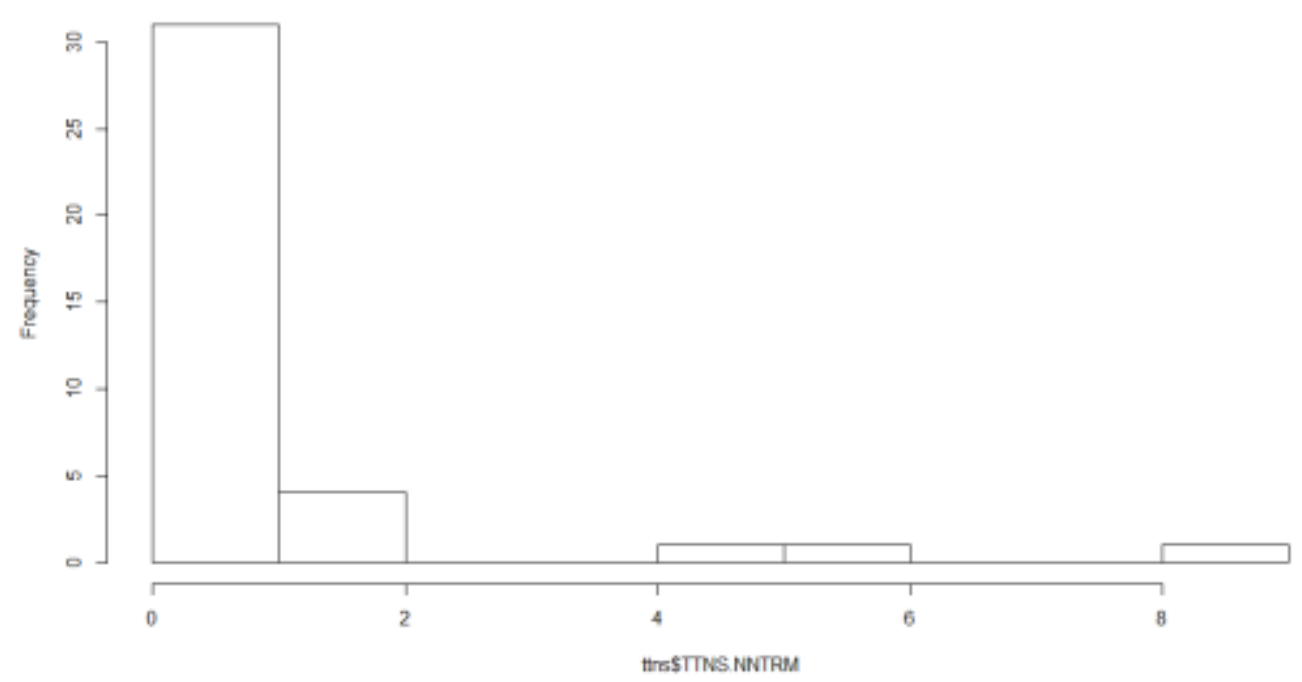

Gambar 1. Data Jumlah Kasus Penyakit Tetanus Neonatorum di Jawa Timur, 2014

\subsection{Pemeriksaan Multikolinearitas}

Sebelum pembentukan model sebaiknya dilakukan pengecekan multikolinieritas variabel prediktor. Myers (1990) menyebutkan bahwa untuk mengecek multikolinieritas pada variabel prediktor dapat menggunakan kriteria Variance Inflation Factors (VIF).

Tabel 2 menunjukkan bahwa semua variabel bebas mempunyai nilai VIF yang lebih kecil dari 10, sehingga dapat dikatakan bahwa tidak terdapat multikolinieritas.

Tabel 2. Nilai VIF Variabel Prediktor

\begin{tabular}{ccc}
\hline Variable & VIF (ZIP) & VIF(Hurdle) \\
\hline$(1)$ & $(2)$ & $(3)$ \\
\hline \hline$X_{1}$ & 1,6932 & 2,1388 \\
$X_{2}$ & 1,8652 & 2,5821 \\
$X_{3}$ & 6,751 & 7,8173 \\
\hline
\end{tabular}

\subsection{Pemilihan Model Terbaik}

Untuk pemilihan model terbaik yang dihasilkan oleh regresi Zero Inflated Poisson dan Hurdle model, dapat dilakukan dengan melihat nilai AIC dari masing-masing model. Semakin kecil nilai AIC yang dihasilkan model, maka model tersebut semakin baik. Berdasarkan tabel 4.3, nilai AIC pada model ZIP sebesar 88,248 sedangkan Hurdle 
Model memiliki nilai AIC sebesar 91,158 sehingga model yang terbaik adalah model ZIP.

Tabel 3. Pendugaan dan Pengujian Parameter Model

\begin{tabular}{|c|c|c|c|c|c|c|c|c|}
\hline \multicolumn{5}{|c|}{ Model ZIP } & \multicolumn{4}{|c|}{ Hurdle Model } \\
\hline $\begin{array}{c}\text { Parame } \\
\text { ter }\end{array}$ & Estimasi & $\begin{array}{c}\text { Standard } \\
\text { Error }\end{array}$ & \multicolumn{2}{|c|}{$p$-values } & Estimasi & $\begin{array}{c}\text { Standard } \\
\text { Error }\end{array}$ & \multicolumn{2}{|c|}{ p-values } \\
\hline \multicolumn{5}{|c|}{ Model log } & \multicolumn{2}{|l|}{ Model log } & & \\
\hline$\hat{\beta}_{0}$ & $5.566 \mathrm{e}+00$ & $1.395 \mathrm{e}+00$ & $\begin{array}{c}6.58 \mathrm{e}- \\
05\end{array}$ & $\begin{array}{l}* \\
* \\
*\end{array}$ & $6.640 \mathrm{e}+00$ & $2.006 \mathrm{e}+00$ & $\begin{array}{c}0.000 \\
932\end{array}$ & $\begin{array}{l}* \\
* \\
*\end{array}$ \\
\hline$\hat{\beta}_{1}$ & $-1.010 \mathrm{e}-02$ & $5.525 \mathrm{e}-03$ & 0.06746 & . & $-1.407 \mathrm{e}-02$ & $8.269 e-03$ & $\begin{array}{c}0.088 \\
920 \\
\end{array}$ & $\cdot$ \\
\hline$\hat{\beta}_{2}$ & $-1.347 \mathrm{e}+02$ & $5.226 \mathrm{e}+01$ & 0.00996 & $\begin{array}{l}* \\
* \\
\end{array}$ & $-1.659 e+02$ & $8.690 \mathrm{e}+01$ & $\begin{array}{c}0.056 \\
236\end{array}$ & 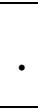 \\
\hline$\hat{\beta}_{3}$ & $-4.263 \mathrm{e}-02$ & $1.546 \mathrm{e}-02$ & 0.00582 & $\begin{array}{l}* \\
*\end{array}$ & $-5.304 \mathrm{e}-02$ & $1.974 \mathrm{e}-02$ & $\begin{array}{c}0.007 \\
205\end{array}$ & * \\
\hline \multicolumn{5}{|c|}{ Model logit } & \multicolumn{2}{|l|}{ Model logit } & & \\
\hline$\hat{\alpha}_{0}$ & -5.87310 & 6.16829 & 0.3410 & & 5.73034 & 4.14529 & $\begin{array}{c}0.166 \\
9\end{array}$ & \\
\hline$\hat{\alpha}_{1}$ & -0.05857 & 0.03074 & 0.0567 & . & 0.01634 & 0.01124 & $\begin{array}{c}0.145 \\
8 \\
\end{array}$ & \\
\hline$\hat{\alpha}_{2}$ & 35.26114 & 129.61085 & 0.7856 & & -158.97377 & 78.23671 & $\begin{array}{c}0.042 \\
2\end{array}$ & \\
\hline$\hat{\alpha}_{3}$ & 0.08621 & 0.07220 & 0.2325 & & -0.06614 & 0.04772 & $\begin{array}{c}0.165 \\
8 \\
\end{array}$ & \\
\hline \multicolumn{5}{|c|}{$\log L=-36.12(\mathrm{df}=8)$} & \multicolumn{3}{|c|}{$\log L=-37.58(d f=8)$} & \\
\hline \multicolumn{5}{|c|}{$\mathrm{AIC}=88.24831$} & \multicolumn{4}{|c|}{$\mathrm{AIC}=91.15769$} \\
\hline Signif. & odes: $0^{1 * * * 1}$ & $0.001^{\prime * * \prime} 0.0$ & *' 0.05 '.' & ט. & & & & \\
\hline
\end{tabular}

\subsection{Pemodelan Jumlah Kasus Tetanus Neonatorum dengan Zero Inflated Poisson (ZIP)}

Untuk menguji kelayakan model ZIP dilakukan pengujian secara serentak (overall), dengan hipotesis:

$\mathrm{H}_{\mathrm{o}}$ : Semua variabel bebas pada model tidak mempengaruhi jumlah kasus penyakit Tetanus Neonatorum $\left(\hat{\beta}_{1}=\hat{\beta}_{2}=\ldots=\hat{\beta}_{j}\right.$ atau $\hat{\alpha}_{1}=\hat{\alpha}_{2}=\ldots=\hat{\alpha}_{j}=0$ dimana $\mathrm{j}$ adalah banyaknya variabel bebas)

$\mathrm{H}_{1}$ : Paling sedikit ada satu variabel bebas pada model yang mempengaruhi jumlah kasus penyakit Tetanus Neonatorum ( paling sedikit ada satu $\hat{\beta}_{j} \neq 0$ atau $\hat{\alpha}_{i} \neq 0$ dimana $j=1,2, \ldots, k$ ) 
Statistik yang digunakan untuk pengujian secara serentak adalah dengan menggunakan Likelihood Ratio Test (LRT). Dari tabel 4.3 didapatkan nilai statistik $\mathrm{GHitung}=36,12\left(>\chi_{8,0.05}^{2}=15.507\right)$. Kesimpulannya adalah menolak $\mathrm{H}_{0}$, yang berarti bahwa minimal ada satu variabel bebas yang berpengaruh terhadap variabel respon.

Selanjutnya dilakukan pengujian secara parsial untuk mengetahui efek yang diberikan masing-masing variabel bebas. Pengujian parameter parsial digunakan hipotesis sebagai berikut:

$$
\begin{aligned}
& \mathrm{H}_{\circ}: \hat{\beta}_{j}=0 \\
& \mathrm{H}_{1}: \hat{\beta}_{j} \neq 0
\end{aligned}
$$

Pengujian parameter secara parsial dilakukan dengan menggunakan uji statistik Wald $W_{j}=\frac{\widehat{\beta}_{j}}{\operatorname{SE}\left(\widehat{\beta}_{j}\right)} ; W_{j}=\frac{\widehat{\gamma}_{j}}{\operatorname{SE}\left(\widehat{\gamma}_{j}\right)}$. Dari tabel 4.3. diperoleh bahwa estimasi parameter koefisien $\hat{\beta}_{0}$ signifikan pada taraf $0 \%$, sedangkan koefisien $\hat{\beta}_{2}$ dan $\hat{\beta}_{3}$ signifikan pada taraf $0,1 \%$ dan parameter $\hat{\beta}_{1}$ signifikan pada taraf $10 \%$. Sedangkan untuk pengujian parameter secara parsial dengan hipotesis:

$$
\begin{aligned}
& \mathrm{H}_{\mathrm{o}}: \hat{\alpha}_{j}=0 \\
& \mathrm{H}_{1}: \hat{\alpha}_{j} \neq 0
\end{aligned}
$$

Pada taraf 10 persen diperoleh parameter yang signifikan adalah $\hat{\alpha}_{1}$. Sedangkan parameter lain tidak signifikan. Model regresi ZIP yang terbentuk adalah:

$$
\begin{gathered}
\log \left(\mu_{i}\right)=5,566-0,01 X_{1}-134,7 X_{2}-0,04263 X_{3} \\
\text { Logit }\left(\pi_{i}\right)=-0,05857 X_{1}
\end{gathered}
$$

Model log memperlihatkan bahwa koefisien $X_{1}$ (cakupan imunisasi TT2+) bernilai negatif, artinya bahwa setiap penambahan cakupan imunisasi TT2+ sebesar satu persen $\left(\mathrm{X}_{1}=1\right)$ akan mengurangi jumlah kasus penyakit Tetanus Neonatorum sebesar 0,01 kali, jika semua variabel lain dalam keadaan konstan. Sedangkan koefisien variabel persentase tenaga bidan terhadap jumlah bayi $\left(\mathrm{X}_{2}\right)$ bernilai negatif, artinya setiap penambahan seorang bidan terhadap bayi sebesar 1 persen $\left(X_{2}=1\right)$ akan mengurangi jumlah kasus penyakit Tetanus Neonatorum sebesar 134,7 kali jika variabel lain dalam keadaan konstan, koefisien variabel cakupan kunjungan neonates lengkap terhadap jumlah bayi $\left(X_{3}\right)$ juga bernilai negative, ini artinya setiap penambahan cakupan kunjungan neonatus lengkap terhadap jumlah bayi sebesar 1 persen $\left(X_{3}=1\right)$ akan mengurangi jumlah kasus penyakit Tetanus Neonatorum sebesar 0,04263 kali jika variabel lain dalam keadaan konstan. 
Model logit menjelaskan peluang variabel respon $Y_{i}$ bernilai nol hanya dipengaruhi oleh cakupan imunisasi TT2+ sebagai variabel yang signifikan. Model logit menunjukan nilai negatif pada variabel cakupan imunisasi TT2+ $\left(\mathrm{X}_{1}\right)$, artinya bahwa penambahan cakupan imunisasi TT2+ sebesar satu persen $\left(\mathrm{X}_{1}=1\right)$ akan mengurangi jumlah kasus penyakit Tetanus Neonatorum sebesar 0,01 kali jika variabel lain dalam keadaan konstan.

\subsection{Deteksi Overdispersion}

Pemeriksaan overdispersi dapat dideteksi melalui rasio antara deviance dengan derajat bebasnya, dimana perhitungannya adalah sebagai berikut:

$$
\begin{aligned}
D & =2 \sum_{i=1}^{n} y_{i} \ln \left(\frac{y_{i}}{\hat{\mu}_{i}}\right) \text { dengan } i=1,2, \ldots, n \\
& =28,87
\end{aligned}
$$

Sehingga,

$$
\begin{aligned}
\Phi & =\frac{D}{n-p} \\
& =\frac{28,87}{8} \\
& =3,6
\end{aligned}
$$

Berdasarkan nilai yang didapatkan diatas, dengan ketentuan lebih besar daripada 1, maka bisa dikatan dalam model terdapat overdispersion. Sehingga untuk mengatasi kasus tersebut dilakukan analisis Zero Inflated Negative Binomial.

\subsection{Pemodelan Jumlah Kasus Tetanus Neonatorum Dengan Zero Inflated Negative Binomial (ZINB)}

Dalam pemilihan model terbaik dapat dilakukan dengan melihat nilai AIC dari masing-masing model. Semakin kecil nilai AIC yang dihasilkan model, maka model tersebut semakin baik. Pada tabel 4.3 dapat dilihat bahwa model regresi ZIP menghasilkan nilai AIC yang paling kecil dibandingkan dengan model regresi dan Hurdle model. Sehingga regresi ZIP lebih baik digunakan untuk model tetapi setelah dilakukan pengujian pengecekan ternyata terjadi overdispersion. Sehingga untuk mengatasi masalah tersebut dilakukan pemodelan dengan regresi Zero Inflated Negative Binomial (ZINB).

Selanjutnya untuk menguji kelayakan model ZINB dilakukan pengujian secara serentak (overall), dengan hipotesis: 
$\mathrm{H}_{\mathrm{o}}$ : Semua variabel bebas pada model tidak mempengaruhi jumlah kasus penyakit tetanus neonatorum $\left(\hat{\beta}_{1}=\hat{\beta}_{2}=\ldots=\hat{\beta}_{j}\right.$ atau $\hat{\alpha}_{1}=\hat{\alpha}_{2}=\ldots=\hat{\alpha}_{j}=0$ dimana $\mathrm{j}$ adalah banyaknya variabel bebas)

$\mathrm{H}_{1}$ : Paling sedikit ada satu variabel bebas pada model yang mempengaruhi jumlah kasus penyakit tetanus neonatorum ( paling sedikit ada satu $\hat{\beta}_{j} \neq 0$ atau $\hat{\alpha}_{i} \neq 0$ dimana $\mathrm{j}=1,2, \ldots, \mathrm{k})$

Statistik yang digunakan untuk pengujian secara serentak adalah dengan menggunakan Likelihood Ratio Test (LRT). Dari tabel 4 didapatkan nilai statistik GHitung $=35.58\left(>\chi_{9,0.05}^{2}=16.918\right)$. Kesimpulannya adalah menolak $\mathrm{H}_{0}$, yang berarti bahwa minimal ada satu variabel bebas yang berpengaruh terhadap variabel respon.

Selanjutnya dilakukan pengujian secara parsial untuk mengetahui efek yang diberikan masing-masing variabel bebas. Pengujian parameter parsial digunakan hipotesis sebagai berikut:

$$
\begin{aligned}
& \mathrm{H}_{\circ}: \hat{\beta}_{j}=0 \\
& \mathrm{H}_{1}: \hat{\beta}_{j} \neq 0
\end{aligned}
$$

Pengujian parameter secara parsial dilakukan dengan menggunakan uji statistik Wald $W_{j}=\frac{\widehat{\beta}_{j}}{\operatorname{SE}\left(\widehat{\beta}_{j}\right)} ; W_{j}=\frac{\widehat{\gamma}_{j}}{\operatorname{SE}\left(\widehat{\gamma}_{j}\right)}$.

Berdasarkan Tabel 4, peneliti melakukan pengujian parameter secara parsial dengan hipotesis:

$$
\begin{aligned}
& \mathrm{H}_{\mathrm{o}}: \hat{\alpha}_{j}=0 \\
& \mathrm{H}_{1}: \hat{\alpha}_{j} \neq 0
\end{aligned}
$$

Pada taraf 1 persen diperoleh parameter yang signifikan adalah $\hat{\beta}_{3}$. Sedangkan untuk parameter lainnya tidak ada yang signifikan baik pada digunakan taraf signifikan $5 \%$ maupun $10 \%$. Model yang dihasilkan dalam regresi ZINB terdiri dari dua bagian, yaitu model dengan bentuk log dan logit. Bentuk log menyatakan peluang variabel respon $Y_{i}$ bernilai positif dipengaruhi oleh variabel-variabel bebas yang signifikan, sedangkan bentuk logit menyatakan peluang respon $Y_{i}$ bernilai nol dipengaruhi oleh variabel-variabel bebas yang signifikan. Berdasarkan Tabel 4, dapat dituliskan model regresi ZINB sebagai berikut:

$$
\log \left(\widehat{\mu}_{i}\right)=-170.306 X_{2 i}
$$

Model log memperlihatkan bahwa koefisien variabel persentase tenaga bidan terhadap jumlah bayi $\left(\mathrm{X}_{2}\right)$ bernilai negatif, artinya setiap penambahan seorang bidan 
terhadap bayi sebesar 1 persen $\left(X_{2}=1\right)$ akan mengurangi jumlah kasus penyakit Tetanus Neonatorum sebesar 170,306 kali jika variabel lain dalam keadaan konstan.

Tabel 4. Pendugaan dan Pengujian Parameter Model

\begin{tabular}{cccc}
\hline \multicolumn{4}{c}{ Model ZINB } \\
\hline Parameter & Estimasi & Standard Error & p-values \\
\hline Model log & & & \\
\hline$\hat{\beta}_{0}$ & 6.2979 & 10.5861 & 0.5519 \\
\hline$\hat{\beta}_{1}$ & -0.0151 & 0.0489 & 0.7574 \\
\hline$\hat{\beta}_{2}$ & -170.3 & 63.3785 & 0.0072 \\
\hline$\hat{\beta}_{2}$ & -0.0446 & 0.0996 & 0.6538 \\
\hline Model logit & & & \\
\hline$\hat{\alpha}_{0}$ & 75.88 & 57.0631 & 0.184 \\
\hline$\hat{\alpha}_{1}$ & -0.5501 & 0.7766 & 0.479 \\
\hline$\hat{\alpha}_{2}$ & 602.5192 & 879.0739 & 0.493 \\
\hline$\hat{\alpha}_{3}$ & -0.7176 & 0.5289 & 0.175 \\
\hline Log L=-0.2479 (df =8) & & \\
\hline AIC $=89.15$ & & & \\
\hline
\end{tabular}

Pemodelan jumlah kasus penyakit Tetanus Neonatorum pada penelitian ini menunjukkan bahwa hanya variabel persentase tenaga bidan terhadap jumlah bayi yang signifikan mempengaruhi jumlah kasus penyakit tetanus neonatorum di Jawa Timur. Hasil ini sejalan dengan penelitian Rahayu, Devianto, dan Yozza (2016) yang menyatakan bahwa persentase ibu bersalin yang ditolong tenaga kesehatan dan persentase kemiskinan merupakan faktor-faktor yang berpengaruh signifikan terhadap jumlah kasus tetanus neonatorum dan penelitian Nusantara dan Purhadi (2015) yang menggunakan Geographically Weighted Zero-Inflated Poisson Regression (GWZIPR) dalam memodelkan kasus penyakit Tetanus Neonatorum di Jawa Timur. Hal ini merupakan bagian dari faktor-faktor prognosis kematian yang disebabkan oleh penyakit Tetanus Neonatorum (Tantijati \& Bantas, 2006).

\section{Simpulan}

Nilai AIC dari regresi Zero-Inflated Poisson (ZIP) menunjukan nilai terkecil dibandingkan nilai AIC yang dihasilkan oleh Hurdle Model, sehingga model ZIP 
dipilih sebagai model terbaik. Pada model $\log \left(\mu_{i}\right)$, regresi ZIP menunjukkan bahwa hasil pengujian secara parsial menggunakan statistik Wald menunjukkan variabelvariabel yang signifikan mempengaruhi peluang variabel respon bernilai negatif adalah variabel Persentase Cakupan imunisasi TT2+ terhadap jumlah ibu hamil, Persentase tenaga bidan terhadap jumlah bayi dan Persentase cakupan kunjungan neonatus lengkap terhadap jumlah bayi. Sedangkan Pada model Logit $\left(\pi_{i}\right)$, variabelvariabel yang signifikan mempengaruhi peluang variabel respon bernilai nol adalah hanya variabel persentase cakupan imunisasi TT2+ terhadap jumlah ibu hamil. Hasil deteksi overdispersi menunjukkan bahwa nilai rasio antara deviance dengan derajat bebasnya sebesar 3,6 sehingga model ZIP masih mengandung overdispersi. Hasil regresi ZINB menunjukkan bahwa hasil pengujian secara parsial menggunakan statistik Wald menunjukkan hanya variabel persentase tenaga bidan terhadap jumlah bayi yang signifikan mempengaruhi jumlah kasus penyakit tetanus neonatorum di Jawa Timur.

\section{Daftar Pustaka}

Amaliana, L., Sa'adah, U., \& Wardhani, N.W.S. (2018). Performa Proporsi ZeroInflation pada Regresi Zero-Inflated Negative Binomial (Studi Kasus: Data Tetanus Neonatorum di Jawa Timur). E-Jurnal Matematika, 7(1), 41-49.

Cameron, A.C., \& Trivedi, P.K. (1998). Regression Analysis of Count Data. Cambridge: Cambridge University Press.

Cantoni, E., \& Zedini, A. (2010). A Robust Version of the Hurdle Model. Journal of Statistical Planning and Inference, 141(3), 1214-1223.

Cox, D.R. (1983). Some Remarks on Over-Dispersion. Biometrika, 70(1), 269 - 274.

Departemen Kesehatan RI. (1993). Profil Kesehatan Indonesia. Jakarta: Pusat Data dan Informasi.

Informasi. . (1994). Profil Kesehatan Indonesia. Jakarta: Pusat Data dan . (1996). Profil Kesehatan Indonesia. Jakarta: Pusat Data dan Informasi.

Informasi. . (2000). Profil Kesehatan Indonesia. Jakarta: Pusat Data dan

Dina, R.A. (2009). Gambaran Epidemiologi. Skripsi. Jakarta: Universitas Indonesia.

Dinas Kesehatan Propinsi Jawa Timur. (2014). Profil Kesehatan Propinsi Jawa Timur. Surabaya: Pusat Data dan Informasi.

Dobson, J.A. (1983). An Introduction To Statistical Modelling. U.S.A: Chapman \& Hall/CRC.

Gujarati, D.N. (2004). Basic Econometrics, 4th Edition. New York: The McGraw-Hill Companies. 
Hilbe, J.M. (2011). Negative Binomial Regression, Second Edition. New York: Cambridge University Press.

Kementrian Kesehatan RI. (2012). Buletin Jendela Data dan Informasi Kesehatan. Jakarta: Kementrian Kesehatan RI.

Kristiono, C. (2010). Regresi ZINB untuk Pemodelan Data Respon Count dengan Excess Zeros (Studi Kasus: Konsumsi Miras pada Remaja). Tesis. Bandung: Program Magister Statistika Terapan, Universitas Padjadjaran.

Lestari, S.P., \& Wulandari, S.P. (2014). Pemodelan Faktor-Faktor yang Mempengaruhi Jumlah Kasus Tetanus Neonatorum (TN) di Jawa Timur dengan Metode Regresi Zero-Inflated Generalized Poisson (ZIGP). Jurnal Sains dan Seni ITS, 3(2), D116-D121.

Mahmudah, U., Cahyati, W.H., \& Wahyuningsih, A.S. (2011). Faktor Ibu dan Bayi yang Berhubungan dengan Kejadian Kematian Perinatal. Jurnal Kesehatan Masyarakat, 7(1), 41-50.

Nusantara, R.K.P., \& Purhadi. (2015). Pemodelan Jumlah Kasus Penyakit Tetanus Neonatorum di Jawa Timur Tahun 2012 dengan Geographically Weighted Zero-Inflated Poisson Regression (GWZIPR). Jurnal Sains dan Seni ITS, 4(1), D79-D84.

Pusat Data dan Informasi, Kementerian Kesehatan RI. (2012). Eliminasi Tetanus Maternal \& Neonatal (MNTE) di Indonesia. Buletin Jendela Data \& Informasi Kesehatan, 1, 1-22.

Rahayu, W.D., Devianto, D., \& Yozza, H. (2016). Pemodelan Jumlah Kasus Tetanus Neonatorum Dengan menggunakan Regresi Poisson untuk Wilayah Regional 2 Indonesia (Sumatera). Jurnal Matematika UNAND, 5(1), 116-124.

Simbolon, D. (2008). Faktor Risiko Sepsis pada Bayi Baru Lahir di RSUD Curup Kabupaten Rejang Lebong. Indonesian Bulletin of Health Research, 36(3), 127-134.

Sugiharto, M., \& Ristrini, R. (2017). Profil Tetanus Neonatorum dalam Rangka Kebijakan Eliminasi Tetanus Maternal dan Neonatal di Kabupaten Bangkalan Provinsi Jawa Timur Tahun 2012-2014. Buletin Penelitian Sistem Kesehatan, 19(2), 149-156.

Tantijati, L., \& Bantas, K. (2006). Faktor-faktor Prognosis Kematian Tetanus Neonatorum di RS Kabupaten Indramayu dan Kabupaten Cirebon. Kesmas: National Public Health Journal, 1(2), 51-56.

Tengah, D.K.P.J. (2012). Buku profil kesehatan provinsi Jawa Tengah tahun 2012. Semarang: Dinas Kesehatan Provinsi Jawa Tengah. 